\title{
The Write of Passage: \\ Reflections on Writing a Dissertation in Narrative Methodology
}

\section{Chaim Noy}

\section{Key words:}

narrative, identity, autoethnography, rite-of-passage, writing, dissertation, modern, postmodern
Abstract: In this essay I explore, reflect upon and theorize my experiences as a doctoral student writing a dissertation in the field of narrative studies. The inquiry concentrates on the problematic tensions that are unique to academic writing in qualitative disciplines, tensions with which I dealt and grappled extensively during my work. I wish to reflect, through the writing of a theoretically informed autoethnography, on the space inscribed between the proposal and the dissertation, and thus on the young scholar's initiation journey through a constructed, narrative-in-becoming space, and on the relationship between the backpackers' narratives of identity and change, which I researched, and my own. In doing so I will evocatively problematize the epitome of the academic rite-of-passage, i.e. the writing of a modern dissertation, in times of post-modern inquiry and writing.

The discussion is informed by the experience of travel and journey which took place between the interviewees' travel narratives and my own (in the form of a dissertation writing); between "field" and "office"; between positivist and interpretive paradigms; between proposal and dissertation, between paternal and maternal sources of writing, and between academic/scientific and poetic expression. The essay offers contributions to the inquiry into reflexivity and subjectivity within the growing paradigm of qualitative methodology, to the inquiry of rites-of-passage into communities and institutions, and it problematizes the possibility that narrative can contain and convey the postmodern, overwhelmed and fractured self.

\section{Table of Contents}

1. Prelude: Where Does a Journey Begin?

2. The Journey from Proposal to Dissertation: How the Doctorate "Broke Free"

2.1 The proposal

2.2 Rethinking the proposal

3. Dissertation Writing

3.1 Authorship issues: Why not write the dissertation with a little help from my friends?

3.2 Forms of presenting writing: Norms of transcribing and editing

4. Mirroring Reflections: Backpacking in Academia

5. Epilogue

Acknowledgments

References

Author

Citation 


\section{Prelude: Where Does a Journey Begin?}

I can see by my watch, without taking my hand from the left grip of the cycle, that it is eight-thirty in the morning.

ROBER PIRSIG, Zen and the Art of Motorcycle Maintenance (1974)

Where does a journey begin?

With a Quest(tion)?

As this one?

With its Writing?

Narrative as a journey.

When you come to think of it, it is difficult to pinpoint when or where a journey begins. Do the backpackers, who I researched in my dissertation, begin their journey upon their arrival in Cuzco or in Katmandu? Or when, on their way there, they make a stop in New York or Tokyo for a few months in order to work and earn additional funding for the extended trip? Or, maybe when they embark on the plane leaving their homeland; or maybe before that, when they typically gather to hear adventure and travel stories of veteran backpackers, and thus are inscribed in the inner circle of backpackers-to-be, as their stories of identity are cast into a communal travel? [1]

And when does the journey of the dissertation begin? ${ }^{1}$ When one travels, "ethnographically speaking" (BOCHNER and ELLIS 2002), and enters the "field"? Or prior to that, when one's dissertation proposal is "accepted" (a minute rite-ofpassage) and the way to travel is charted? Or when one is accepted to a graduate program? Or before that, when one embarks on his academic journey and enrolls as an undergraduate? Or even earlier, when one's father is a professor of Jewish folklore and one's mother an archeologist, and some nebulous and vague narrative dream is crafted during latency years, to be awakened and pursued years later?

I remember playing with my father's endless stacks of draft papers, rough, worn, on their blank, clear side. All retrieved from a large and dark space that laid between two platforms of thick, dark wood, that formed my fathers' timeless desk.

I was always generously permitted access to this abundant supply of draft papers. I don't remember what specifically I wrote, nor what were the many words written on the back of the used papers (probably correspondences in Yiddish, drafts of publications hammered into the paper by a typewriter, corrected papers his students' handed in, and the like). I just remember it was there, on the backside, a presence. Signifying something else. Raising my head I would see a fading picture on the windowsill. His parents. Overlooking the writing desk. Overlooking the writing. The background is not clear (in my memory?) Kolomia, Galicia. The twenties or thirties. ${ }^{2}$ [2]

1 Though I am referring to the dissertation, all that is said holds equally for theses writing and perhaps for additional forms of writing in academia.

2 Following GUREVITCH's (2000) search of his "fatherly" sources of writing. 
With narrative, wondering where does it all begin is intelligible. But, how to start writing? That is, how to write-and how to read-one's reflections on oneself in a theoretically rich and informed fashion. Autoethnography is a genre that suggests innovatively that in some cases, writing about and through oneself, is scholarly illuminating. The writer addresses herself or himself ("auto"), as a subject of a larger social or cultural inquiry ("ethno"), vis-à-vis evocative and revealing writing ("graphy") (ELLIS 1993 1999). The work tells of those constitutive dimensions that in ordinary, conventional scientific language are erased or play a backstage role. These include personal, lived experience and voice, relationship between researchers and their work, processes (rather than results or products), etc. (RICHARDSON 1997). [3]

There is no recipe, or one, correct way of writing an autoethnography. For example, in a few of the works in the field theoretical issues are either entirely implicit, or they are referred to scarcely (DENT 2002; RONAI 1999). In such cases the contribution revolves around the writers' intimate knowledge of the subject matter, and the texts' complex articulation of it and its innovativeness. In other cases the theoretical and the personal perspectives or voices are both explicitly presented, sometimes separately (ELLIS 1993), and sometimes in an intertwined way, where they are in dialogue throughout the text, and where this dialogue is what weaves the fabric of the text (GUREVITCH 2000; JONES 1998, 2002). Presently, I found the latter to be the most suitable possibility, conveying my own struggles throughout my work. In all cases, and in this one as well, the text articulates an evocative personal narrative, as it wishes to touch and move its readers in ways that are not only metaphorical; it is indeed, a heartfull writing (ELLIS 1997, 1999). [4]

And it is precisely from the perspective of narrative research (specifically within psychology) that I wish to touch on and to problematize a few mainstream notions about narrative. According to some scholars people's lived experiences and life stories are conceived as carrying such qualities as, "unity," "purpose," "direction," "followability" and etc., as they "convey" an inner psychic reality (McADAMS 1993, 1997; McADAMS \& BOWMAN 2001). While writing the following it become clear to me that it might be modern scientific research that frames stories of lives and of lived experiences in terms of coherency and progression, while postmodern narrative may be perceived as a less coherent and more fractured genre, and as a genre that does not only convey or reflect upon ones' identity, as it evokes, performs and constitutes it in the event of narration. In stressing the texts' polysemy and multiplicity, I am inspired by Umberto ECO's work, and particularly by ideas proposed in the Open Work (Opera aperta, ECO 1962/1989). The complementary notions of "ambiguity," on the one hand, and "openness," on the other hand, suggest quite a different hermeneutic frame for narrative inquiry: a combination/contamination of genres that continuously evolve, and inspire new meanings, between writer and reader, teller and interlocutor. [5] 


\section{The Journey from Proposal to Dissertation: How the Doctorate "Broke Free"}

"It is by now something of commonplace within the theory of travel writing to acknowledge the ways in which travel is a form of writing and writing is a form of travel."

Susan STEWART, Crimes of Writing (1991)

\subsection{The proposal}

Looking back now at my doctorate proposal, dated July 22, 1997, I find that, interestingly enough, its title has nothing to do with my proposed research. It is rather a statement concerning the formal status of the document, signed five years ago: "A research program submitted for approval as a dissertation plan." The title is followed by strings of little letters, to which I never seem to pay any real attention, running my eyes across them quickly, dismissing their potential trouble as "mere bureaucracy." Towards the bottom of the page the title of my work is printed: "The Great Journey: Narrative Analysis of Israeli Trekking Stories." And by its side are my advisors' and my own printed names, accompanied by handwritten signatures: lively blue and pink-Amia's pen-ink, conventionally signifying authenticity/singularity (DERRIDA 1988). The next occasion anyone would be signing anything will be four years later, on the cover of the bound dissertation monograph. Regrettably, these are the only two occasions of handwriting, of that "track of the body" (STEWART 1993, p.14). Atop the proposal and the submitted dissertation, atop the outsides and bounds of the work, seals confirming authenticity. Rather than inside, within, embodying the text, breaking, even slightly, with printing conventions. [6]

The dissertation's proposal, I realize, is written as a contract, as a legal binding document. It describes what task the researcher takes on her/himself, and how s/ he is going to carry it out. The language is authoritative, conveying the author's supposed knowledge of the field and of the genres constituting it. As the italicized "proposal" suggests, it is a contract which is written in future tense-it is a prospective program depicting a trajectory of the "theorology" (theory-andmethodology) along which the researcher will travel in order to reach the sought after "scientific" destinations. The theoretical discussion should rationally lead to the methodological procedures, and these should systematically lead to the presumed "findings." While in positivistic and post-positivistic research some room is left for what the results might be, the structure leading to the outcome, i.e. the journey, the narrative, is not negotiable. It is a convention, not a conversation; and the proposal is the journey's schedule or itinerary, which is agreed upon at the outset. [7]

In discussing a new and more creative framework for writing proposals for narrative dissertations in psychology, JOSSELSON and LIEBLICH (2002, p.260) offer what seems something more general and applicable to a variety of qualitative fields: 
"In that narrative research is a voyage of discovery-a discovery of meanings that both constitute the individual participant and are co-constructed in the research process-researchers cannot know at the outset what they will find ... In most psychology graduate programs, the structure of thesis or dissertation proposals is dictated by the paradigm of quantitative, positivist research. Hypotheses to be tested are set out and located within the research tradition or theory from which they emerge. Methods are employed to test the defined hypotheses. Statistical analyses that will be conducted are specified ... Introduction, Method, Results and Discussion." [8]

In my dissertation journey I set out to inquire into a collective social phenomenon in Israel, that of an extended backpacking trip to faraway destinations normatively undertaken by young, Jewish, middle class, Israelis, soon after they complete their mandatory service in the military. The main body of the proposal, the "theoretical background," included three parts addressing three discrete, yet converging conceptual perspectives: the backpackers as pilgrims, as tourists, and the specific cohort of young adult backpackers. [9]

When I submitted the proposal for approval, in late July of 1997, I honestly thought these were the main theoretical issues I would and should be concerned with and researching in the following years. A comprehensive, systematic and tiered research was suggested, approaching the field of backpacking tourism through broad inquiry drawing upon the three different theoretical viewpoints. [10]

Such was my idea at the outset. [11]

However, following JOSSELSON and LIEBLICH (above), and considering that in a field where process and hermeneutics are part and parcel of our work-a field defined by "a series of tensions, contradictions and hesitations," (DENZIN \& LINCOLN 1994, p.ix) - it can hardly be imagined that such a work would (or should) develop precisely or even approximately along the proposed lines. And so, slowly but surely, the dissertation began drifting away from its proposal. To my protests and growing anxiety I realized that if someone would have looked at these two documents - the earlier, preceding and binding one (the proposal) and its consequence or result-only a loose connection, if any, could be found linking the two. [12]

The dissertation consisted of two large chapters that, again, as if against my will, were each some two hundred pages long. Not something that I planned for, nor that I would have wished for, and neither of which dealt with the three topics I had described and committed to in the proposal. [13]

The first chapter reviewed the voices in the stories backpackers repeatedly tell and hear. "Where did that come from?" I continually asked myself. From semiotics to conversation analysis, and from socio-linguistics to narrative analysis I unintentionally wrote an essay about how backpackers construct an intertextual canon and how they quote and voice it in their narratives. The second chapter was an inquiry into the body as a social site, and was informed by feminist and by sociological theories. The embodied narratives I found unfolding were presented 
mainly by women backpackers-women engaged in an activity culturally constructed as masculine and macho-demanded different reading, interpretation and presentation, one that was itself embodied. [14]

"Up in my head" I knew that such narratives of personal experience suggest and open a nearly endless variety of readings which creatively envelop, as a result of the encounter between the material and the researcher, the literature and ideas he is exposed to, and so on. This composes the researcher's journey. But this knowing did not ease my emotional unrest. I was trapped. I felt quite bad about the directions things took. I felt, and I must admit it sounds harsh, that I was deceiving and not being reliable (but to whom?). I felt I was doing something wrong. In addition, and as a consequence, I also felt I was letting someone down, someone important, perhaps an imagined "anonymous reviewer" of my work. I had promised something that I failed to deliver, and I delivered something that was not asked for (and might have not received approval to begin with). It is not that I compromised one proposed perspective or another, but that I simply took an entirely different direction (or it took me...). Looked at narrowly, one large conceptual step or phase was missing between the initial proposal and the final dissertation; seen more broadly, what evolved was simply a different work altogether. [15]

As I write these lines now I ponder: Doesn't a "different work" amount to a "different researcher?" Isn't writing a becoming? (MINH-HA 1989; RICHARDSON 1997). ${ }^{3}$ Are we not in writing ourselves changing, transforming? (FLEMOS \& GREEN 2002). Could we understand the dissertation as a journal, as a scholarly diary of sorts? If so, was I different? Did the Chaim of '97 differ from the Chaim of '01? Did Chaim of ' 01 adhere to the expectations, programs and promises of the former Chaim? [16]

\section{Should have I done so? Did I go astray? [17]}

But somewhere in my body it was clear: The further the better. The further the dissertation breaks free and drifts away, the further it journeys, the more generative and creative the processes that occur. The further the better.

I practice a pacifist form of a martial art called Aikido, a relational social practice. I have learned much about my work and myself through the Oriental concept of Tao, the Way, or the Japanese Do—as in JuDo, Karate-Do, and flower arrangement kaDo (ikebana). Interestingly, Do is translated as either "The Way of ..." or "The Art of ..." In my practice I conceive of the "Way" as referring to the systematic, arduous, and painstaking dimensions. It involves the whole of the living person and is not confined to the mental or intellectual life. At the same time, Do is also an "Art." In this sense it conveys the creative, that which is not planned, linear, and progressive. It has to do with generativity, innovativeness and spontaneity.

3 Also TYLER 1986. Specifically concerning qualitative dissertation and thesis writing see GARRET (2000), and MELOY (2002). See Note 8. 
During the years of researching and writing the dissertation, I have humorously referred to myself as a Do-ctorate student. The dissertation was for me both a "Way" of practicing and at the same time an "Art" of exploring, each complementing the other. [18]

It was only later, in hindsight, that it dawned on me that the change and development of my interests and research was closely related to other work I was doing at the same time, other theoretical investigations that I pursued intensely. That change, or shift, I began to see, was a natural consequence of intellectual and scholarly growth, and it unfolded within social, organizational and research contexts (RICHARDSON 1997). But at the time of writing I could not validate or justify what was happening. I was more than bewildered with my intense interest in voices and bodies in the backpackers' narratives, and with the shape and size it assumed in my work. The shape and size, and the fact it had not even been mentioned in the proposal, suggested to me that it might be too idiosyncratic. Too much a reflection of "my own" interests, of "my own" agenda, I thought. [19]

\subsection{Rethinking the proposal}

Thinking about the proposal retrospectively and more theoretically, I have come to feel that the proposal had exhausted the theoretical fields it dealt with at the time it was written. I gradually came to conceive of it not in terms of a legal prospective document, but as a more personal and reflexive chapter in a continuous journal, the journal of my research journey. Rather than excluding it from the body of the work, and defining as contractual the tensions that arise from such exclusion, I wish to think of it more inclusively. The proposal thus might not propose what is ahead, but instead reflect on and convey the current position and state of the researcher in relation to theoretical, methodological and presentational matters. Instead of a binding prospective document, we would arrive at an "academic journal," serving as a significant point of reference for the researcher him/herself, as well as for other readers, such as committee members, allowing all an impression of the researcher's current "place." The proposal in this sense is an "introduction," a "first-step," an open reflexive chapter in a longer track, which it both referentially marks and performatively presents. It is not an obligating, binding program that negates the possibility of surprise, or the open-ended ways in which the research and the researcher could develop. A posing, rather than a proposing. [20]

Indeed, I regret not making more use of the proposal as means to probe inside myself and inquire where I am now, or where I am at currently in regards to the material I am working with. Such inquiry would generate a reflexive, hermeneutic document rather than a positivist one, a document that describes rather than prescribes. This is not to suggest that we omit discussion of theory and literature in the proposal altogether, but that these discussions should not be directed towards the future; instead, they should reflect on the present and the inner. ${ }^{4}$ [21]

4 I feel a word of caution is needed. Some contractual aspects of the proposal might come as very useful to the doctoral student, since a contract is, after all, a two-way commitment. Just as it commits the researcher it also commits the institution, in the form of a dissertation committee. 
This implicates the dissertation. I do not view it now as a product, an end product located at the end of a stressful manufacturing line, but as a reflection of its own becoming. A reflection of the numerous ("everyday") hesitations, challenges, fallbacks, breakthroughs, frustrations, illuminations, satisfactions, and insecurities that we encounter and which comprise the silent, or silenced, fabric of our work.

A Yiddish proverb comes to mind, "Men tracht un Got lacht." (Lit. "men plan and god laughs"). It points to the complicated tensions inherent in perceiving the flow of time and in the primordial human wish to plan what is "yet-to-be" ("avenir"), i.e. to grant it "intelligibility or interpretability" (DERRIDA 1990, p.993). God, so it seems here, does not laugh at humans for no reason, nor does he or she laugh over our troubles or misfortunes. He or she does have a laugh, though, at our attempts to tame time and to control it. Science, as a primarily modern and masculine endeavor of prediction, is embodyingly funny for him or her. [22]

\section{Dissertation Writing}

While so far I have reflected on the space inscribed between what is proposed and what later materializes, I now discuss some issues concerning writing itself. The first concerns my unfulfilled wish for shared writing, the second stylistic matters of presentation with which I grappled in the dissertation. [23]

\subsection{Authorship issues: Why not write the dissertation with a little help from my friends?}

Individualism and Enlightenment, and specifically scholarism, developed side by side during the same era not by coincidence. In "Crimes of Writing," STEWART (1991) points to the initial perception of authorship and the right of intellectual assets, such as ideas, as well as the socio-historical circumstances that bred such notions in the eighteenth century. Following FOUCAULT's discussion of Hobbes, STEWART refers to the "conventions of attribution" (p.9), and points out that

"[t]hese concepts set the stage for the seventeenth-century development of the classical liberal principles of intellectual property ... The idea that no one is so much the master of his goods as a man is the master of the products and of the labor of his mind would emerge in a complex figuration regarding the nature of work, materiality and ownership, and, eventually, the relation of these concepts to mental labor and originality ... the idea of personal ownership of words, or certainly personal ownership of the order of words, was not available" (pp.9-10; also RICHARDSON 1997, pp.12-22). ${ }^{5}[24]$

In cases of misunderstandings, some clear description of the scope of the work is well advised. (The main site where negotiation concerning what is expected of the graduate student, and what has indeed been achieved, takes place is the dissertation committee meetings, a subject which demands an [auto]ethnography of its own [see JONES 1998, pp.132-152]).

5 Vicissitudes, including downright reversals in such "conventions of attribution," date back, as Stewart points, at least to the early Middle Ages in an interplay between two dichotomized metagenres: "scholarly work," on the one hand, and "literary work," on the other. It is clear that the problematization of what these "genres" are, or of what "attribution" means, would require a revisiting of writing and inscription from its beginnings. 
Now, there is surely an inclination in academic circles towards single authorship (co-produced publications being exception to the rule), but there is no place in this writing scene where single authorship is so vehemently and orthodoxly observed as in the case of dissertations. Of any other legitimate co-produced kind of work (from a seminar paper to an encyclopedia), the dissertation can hardly be even imagined as co-authored or co-composed. Located at the heart of the academia writing a dissertation and graduating is a form of an institutionalized rite of passage or, better, rite of institution. This rite, which is historically embedded in the age of Enlightenment, constitutes an inherently modern and individualistic rite of passage; it constitutes a modern scholar in a modern institution. [25]

My encounter with the implicit restrictions surrounding single authorship was powerful, since I had both a need and desire to share my ideas and to discuss them with fellow young researchers who have researched Israeli backpackers and written thesis and dissertations (or were researching/writing) on the subject in the last few years. ${ }^{6}$ That is, I did not want only to discuss these matters and then confine myself to my own solitary, or simply mention my colleagues in the references dubbing them as "personal communication." Instead, I thought these discussions had the potential to inject original ideas, ideas at least as worthy as my own "intellectual products." (STEWART 1991) [26]

Where does it say, I thought, and where is there proof that collecting data, analyzing and interpreting it, and presenting knowledge in a solitary manner is preferable somehow to doing so in collaboration? If I was anyhow daydreaming of having conversations with my colleagues, I wondered why not really (literally) discuss it with them and include these conversations it as an integral part of my piece. [27]

ELLIS and BOCHNER $(1996,2002)$ suggest, and demonstrate, a dialogic genre in which social knowledge is both created and presented at the same time.

Relational social constructivism suggests that this is how knowledge is in fact created (GERGEN 1994, 1999). So why was there no room for this in the dissertation? Furthermore, the work of HANDELMAN $(1993,1994)$ and RICHARDSON (1997) suggest that it is the institutional structure of our individualistic "careers," and not something else, something "natural" or "essential," that leads us to neglect the voices of those colleagues who we engage. From our work are "absent" (HANDELMAN 1993) the voices of fellow scholars, colleague-friends, and close members of our community - the very community which shares with us —echoing, citing, resonating, amplifying—ideas. [28]

Originally my idea was to send the chapters I wrote to my colleagues and ask for comments and elaboration on my ideas to whatever extent they found suitable. Since those chapters included discussion of their work I wished for a conversation, a mini symposium to take place within the boundaries of my dissertation. A conversation that, undoubtedly, would illuminate the common

6 Such as AVRAHAMI 2002; BLOCH-TZEMACH 1998; MAOZ 1999; MEVORACH 1997; SALMON 1998; and SIMCHAI 1998. For a review of the works see NOY (2002b). 
subject of our research in a valuable way. This way, I thought (and I still do), readers of the work would be exposed to more than one perspective or voice (mine), and would be able to read in the same compendium comments and reflections, even critiques, on both my ideas and the contributors' own previous work. Such a move promised to enrich the piece, to make it polyphonic, even. [29]

But the more excited I grew, the stronger were my hesitations. My early enthusiasm led me to believe that this debate would take place inside the work itself, forming an integral part of it. Gradually, as I came to see that a collaborative doctoral dissertation would by no means be accepted, I considered moving-downgrading - the discussions and conversations to the appendix, that area that lies somewhere at the fringes of personal authorship (where questionnaires are attached, whole transcriptions found, and so on). [30]

However, I must admit that these ideas were not put to the test, and for a few reasons. First, the message I received from my immediate academic surroundings, though subtle, did not convey the usual enthusiasm I enjoyed. By no means was there any outright opposition to the ideas, but rather, they were viewed as a curiosity, an anecdote, a questionable addition that might or might not do any good. One of my mentors actually said, "that's a nice idea, Chaim, but now get on with your work." My enthusiasm over the new venues of knowledge was not shared, and since I constantly felt I was late anyhow in the dissertation schedule, and was anyhow ridden and anxious with my wrongdoing in regards to the proposal (as I mentioned above), it didn't take much to tame my creative enthusiasm. Secondly, I must admit there was also an apprehension on my part, stemming from the fact that I was going to introduce my ideas, in their entirety, still unbounded and "unsigned," to colleagues working in the exact same field. I wasn't too sure about that-would they reciprocate? Would they show openness to my initiative? Would they not call these ideas their own? I was ashamed by some of my thoughts, which reiterated some of the aforementioned ideas of "intellectual ownership" rather then resisted them. And shame, to be sure, did not revitalize my enthusiasm and creativity. [31]

So finally I relapsed and confined myself again to a more traditional format and compromised for a detailed dialogical review of my colleagues' work (see Note 6), which took the shape of a sub-chapter. Indeed, I was its sole author, yet the writing style was not the custom theory-oriented literature review, but more a close and detailed—and "personal" or dialogical—discussion with their voices and works. I felt it gave my fellow researchers more light and space than they would have received if I were to review their work conventionally. [32]

\subsection{Forms of presenting writing: Norms of transcribing and editing}

The move from the proposal to the dissertation was also a move from the pragmatic or instrumental to the expressive and artful. While the former was a document indicating what the researcher should attain, the latter was the materialized conclusion of the work. However, when writing it, it was clear that the work could not be conveyed in the genre suggested by the proposal. So it was 
more of a bottom-up kind of process where I tried to fit the right lid on the pot the interviewees - the backpackers-and I had crafted, rather than making a conscious decision that I should write in a different way (engaging, as DENZIN [1999] put it, in a "guerilla warfare against the repressive structures of everyday lives" [p.572]). I thought that if writing is a "mode of thought" (BECKER 1986; RICHARDSON 1997), then I should search for the most appropriate mode of thought for my work. [33]

Trying to give voice to personal experience is quite impossible when it comes to positivist language, which addresses a presumed "universal, passive, unengendered reader" (FRANK 1995; RICHARDSON 1997; SPARKS 2002, p.218). In this case-where I found myself researching bodily experiences that were narrated by women backpackers, I faced the need to compose a new terminology where traditional or conventional terms either did not exist or carried irrelevant associations. I was exploring a language of research and representation, and this creating of language, which was at the onset only instrumental, gradually became a goal in and of itself. Struggling with how to write the experiences of a "lived body in motion," I could not resort to using a traditional type of supposedly neutral writing. The need to give a vivid and tangible feel to the bodily experiences backpackers were narrating was a scholarly responsibility, and an intellectual endeavor and challenge. I have grappled with it on two separate levels: The visual representation of the different voices presented in the work, mainly through forms of transcription, and structural or editorial decisions, pertaining to the adequate presentation of the experience of bodies immersed in adventurous narratives. [34]

The first issue dealt, then, with finding the appropriate visual format for the transcriptions. This was a relatively easy task, as I had whom to learn from: ethnographers and linguists of conversation and storytelling have long grappled with this question, and have fruitfully pointed to ways in which transcribed text can be graphically represented in an evocative and poetic form. The presentational convention according to which the informants'/interviewees' words are represented in a block marked and separated from the text by double space was problematized. TEDLOCK (1983), to mention but one voice, has suggested that the visual formatting of the text represents in fact its interpretation. There is no "neutral" formatting, and the boxed and justified representation of the oral excerpts carries an array of implications, among which are moral ones. The presentation of transcription had to do not only with the interpretation of the transcribed vignette, but also with conceptualizing its genre; is it poetry, prose, etc. (TEDLOCK 1983). The different genres are presented in different graphic and spatial forms. [35]

Quite paradoxically, it was only in the "methodological chapter," in which usually the limits are set rather than challenged, that I allowed myself to experiment with such representations. These presentations suggested reading/listening to some parts of the backpackers' stories as rhythmed narration, as poetry. This was of particular interest, and nearly vital, when it came to embodied narratives of movement. The texts describing the body in motion had to move their readers in 
a way that conveys the trance like feelings the women backpackers were narrating. The rhythm of the oral narration was transformed into a poetic written transcription, mimetically conveying the embodied and enspaced experience, reflecting and evoking the ways in which body and space were experienced and performed. When the backpackers narrated the strenuous experience of climbing the high mountain, their words were delivered in a way conveying their heavy breathing; when they narrated the hurried "falling down" of their bodies from the peaks and passes of the mountains they trekked, so were their texts presented in hurried words, stumbling down the page, leaping lines and wordily distances. [36]

In other cases it was my own words that needed different, less traditional, graphic representation. So was the case when I recalled my own memories as a backpacker, a decade earlier, in the form of personal vignettes. In that case I wrote memories from and reflections on the travel, depicting my experiences in a more poetic and style-conscious manner. [37]

The second aspect I grappled with concerned not the more visible graphics of transcription and printed word, but the structure of the work and the editorial decisions having to do with the divisions and contents of chapters. Again, I found myself at odds with some basic tenets of scientific-positivist scholarly writing. I found the structuring of the relationship between chapters and subchapters quite difficult: While scientific writing forms are linear, and entail hierarchical distinctions and categories, I felt that my work was not a really linear or ordered development of concepts and could not be represented well in orderly forms of writing. [38]

Some subchapters had the quality of what William LABOV designated as "floating phrases" (1972), i.e. they could fit just about anywhere as they were "nonnarrative." Other parts could hardly fit under any title and would require new labeling and new chapters. While some of the writing could have resorted to more traditional forms, the "lived experience" component of the work, the embodied quality of the narratives, and the way in which I read the texts simply had to be expressed through a different kind of less rigid, ordered, and hierarchical writing (HANDELMAN 1993). The work I wrote seemed, and I regret to say that it in fact was marginally organized. It was quite "messy" (DENZIN 1997); only "near" the spot (LAU 2002, following IRIGARAY 1977). ${ }^{7}$ It hardly had any overarching conceptual hypothesis that was studied systematically throughout the dissertation, and if there was a governing point to the dissertation, it was not explicitly spelled out within it. I was not able or not successful in crystallizing a clear "vertical structure" of knowledge, and, needless to say, in laying it out linearly and progressively. [39]

My (last) hope was that while engaging the work, readers would transform from commentators or critics, reading an account of the development of a hypothesis,

7 FRANK (1991), too, emphatically uses the term "messy" when he refers to embodied experience and text, as opposed to disembodied, neutral and all-knowing genres (pp.53, 61). Following SCHWARTZ (1986, cited in FRANK 1991), FRANK reiterates the phrase, "the truth was a mess," which, he adds, "any general theory should hold as epigrammatic." (p.53) Writing of livelihood, of corporeal and lived existence, seems to me, thus, to be "messy" by its definition. 
into readers who moved along "with" the work (FRANK 1995, p.23). This would mean following how I was trying to create meaning and meaningfulness, however idiosyncratic and fragile the path. Through that process I produced a kind of writing different than any I had previously known, and a kind of writing different than any I had written before. I wished that my readers, and especially the anonymous judges, would be able to bear its "messiness," not to mention to enjoy it and benefit from it.

When he hands me back a few chapters he read I hear my advisor quietly muttering: "Good work, good work,

but

Who should be its judges ..." [40]

Dialogical thinkers:

Mainstream academic writing makes it tough for dialogically or relationally oriented thinkers. As mentioned above, academia is a modernist post where individuality is vehemently pursued and repeatedly constituted. Myself, not only do I share ideas with colleagues, or borrow them, "steel" them etc., but when reading others' works, I strongly feel that the conversation created between us is the primary mode of knowledge creation. Works have their way of "touching" and "moving" me into emotions and actions with an intensity that surprises me time and again (most recently JONES 2002). And so the "literature review" sections in my publications are usually in the form of a dialogue (open ended), rather than a monologue (conclusive). I am constantly commented in this regard. I am asked by reviewers to address unmediated "knowledge" directly, rather than from within the relationship or connection I "feel" towards it voicers. But I love conversing with fellow thinkers through their writing. The fact is that when I receive a new publication (usually after having read thoroughly the copy in the library), I look through the pages quickly and think I have a wonderful new space/place in and on which to write, i.e. to comment and converse (JACKSON 2001). [41]

\section{Mirroring Reflections: Backpacking in Academia}

As the research journey progressed the similarities between the backpackers' narratives and my own doctorate research crystallized. In both cases, a mixture of romantic and modern images and archetypes of travel and self-transformation were at the core, allowing the construction of the explorer's or the scientist's progress (GREEN 1993). Both endeavors, backpacking as hiking-and-narrating, and the dissertation as research-and-writing, seemed to be discursively constructed and structured as a rite of passage. [42]

This is evident in my colleagues' experiences as well. Doctoral students typically mention the "journey" they have gone through, the "way" they have traveled and progressed from the beginning of their work to their current state. The metaphor of the journey, at times Romantic (a propos nature) and at times modern (a propos science), means that the experience of becoming a scholar is that of the 
individual arriving at new destinations or colonies of knowledge, previously unknown. This is one of the foundational metaphors of modern science, i.e. its progression unto "terra incognita" (BOORSTIN 1983, cited in JOSSELSON \& LIEBLICH, 2002; GREEN 1993). ${ }^{8}$ Of course, the institutional metaphor is embodied in the scholar personally, in his or her vectored career: through and throughout their careers scholars are expected to perform a rites-of-passage and to reiterate it. [43]

The similarities between my endeavor and the backpackers', that is, between the discursive construction of both the dissertation exploration voyage and the backpacking journey, stood out most clearly in the realm of narrative. They are both stories of a rite-of-passage by which the individual enters in and accesses a cultural capital. More importantly, both socially constructed stories of rites-ofpassage are ritualistic in that the meaning they carry is mostly symbolic. Regarding the backpackers, I soon realized that it could be said that they travel for the stories. They travel after they have heard numerous stories, which preshape the itinerary of the travel and the experiences it bestows. And they progress and "mature" during the trip-they all declare they do-in correlation with the achievements that such (predominantly romantic) journey and adventure narratives entail (ELSRUD 2001; GREEN 1993; NOY 2002a, 2003, forthcoming). Both the personal stories and the larger social and institutional narratives are those of a rite of passage, i.e. of a meaningful self-transformation. And this sought after personal change is achieved through owning a story, which the particular events of one's actual journey validate. Veteran backpackers own stories, and are entitled to tell them (SHUMAN 1986). They gain the right for audience. [44]

The parallels with the doctoral dissertation, as a symbolic (w)rite of passage, are telling. Consider this: How many people read dissertations? Or, why do disciplinary conferences within the larger social sciences regularly devote sessions to "How to make a book of your dissertation?" Part of the initiation of the "young scholar" is to go through an institutionally constructed "basic training" in order to test her/his worth and to grant her/his formal and social seals allowing entrance into the academic arena. For by no means is there an "inherent" need to pursue research in the monograph fashion of the dissertation. [45]

In any case "young scholars" are expected to publish papers and books based on their work, and these publications are the ones that carry weight when career decisions are made. Similar to travelers, young scholars are expected to "travel," and, at least as important, to compose and write a narrative of their successful (predominantly modern) journey. Although backpackers mostly tell stories, and scholars mostly write them, the narrative dimension of their journeys is constitutive. In his discussion of the "adventurous white male mind' GREEN (1993) writes that, "modernity starts with the adventure tale" (p.148), which, in our

8 See also My Qualitative Dissertation Journey (GARRETT 2000), and TOPOL (2001), which autoethnographically present the journeying and the transformation of women writing dissertations in qualitative fields. Such works are touching and revealing particularly in their feminist perspective on the dissertation as a masculine initiation into the modern masculine institution-the academia. 
case, refers to the journey narrative. Central to modernity is the scientific endeavor wherein emphasis is put on experimentation. Citing MERCHANT, GREEN writes, "experiment expresses the spirit of action, of a 'doing' devoted to 'finding out'" (my emphases, p.144). [46]

A final note concerning modern versus post-modern morality is required here. The structure of a self-transforming journey, of a rite and right of passage, is pregnant with value; it is a form of cultural/narrative capital, and it endows the successful practitioner with certain esteemed merits. In the modern version, carrying the dissertation about "successfully," i.e. completing it within the designated time frame, and within the theoretical and methodological frames proposed at the outset of this modern quest, denotes a complete narrative of a rite of passage. The ensuing and sought after moral revolve around the virtues of commitment, dedication, obligation and fortitude. In contrary, post-modern and post-structural dissertation endeavors, where the research's structure is negotiable, and is at least as much a process as it is a form, and where reflexivity is central, a different morale is bestowed. Here, improvisation, intuition, candidness, and personal as well as social and cultural sensitivities, are sought after and valued. The different narratives of rites-of-passage educate the young scholar along different avenues and endow him or her with a different moral code: One more conservative and one more liberal, one more "serious" (GUREVITCH 2000), and the other more playful, one more abstract, the other more embodied. Neutrality is exchanged for involvement, passivity for agency. [47]

As with backpackers, I also acquired the right to a story through "going out there" and "going through the motions," i.e. through the empirical-experimental paradigm. As with backpackers, I too could have not confined myself to my room when researching. There would have to be a "field," which would be constructed, and then "journeys," which are movements to and from; as with backpackers there is a single, clear model of a successful story, which has to do with coherence, unity, linearity and progressiveness. Stories that are "messy" are considered both troubled and troubling, and more than representing an alternative, they represent a disappointment. And lastly, since these are stories of passage and initiation, i.e. of belonging, messiness and disappointment are faults that lead to non-admission or non-entrance.

As I finish writing the first chapter, a large essay on voices and quotations in narrative, and hand it to Amia and Yorm to read, I burst into tears.

I know now that the dissertation will be; that it is.

I am overwhelmed.

I am crying. My mother. I am feeling my mother. From whom I inherited my writing; my writing disability.

And then back into the everyday frustration of writing the next chapter, and the rewriting of the next chapter, and the next ... 
Twice a day she was spared. Momentarily. Before falling asleep and at dawn ideas flowed through her, complete, ideal, worded perfectly. She said to me, "These ideas, I had them... I held them..." But with any move she made, any move to seize them or record them, they would dissolve. This was the curse. I know it well (I'm writing it). She took comfort in my father's fluent writing and in my own. She hoped I could help her write. The irony.

I'm thinking, writing and/in/as living. Connect all the lines of the letters you wrote, the ballpoint-pen ink, fountain-pen ink, and printer ink to a long (seismographic) line of life. When it ceases-so do you. Writing like biting on something sharper than your teeth. Like scratching your skin too deep. Chasing phantoms. I, even I, could not comfort her/myself. And I cannot hope for or help her anymore. I myself am not "hoped." Writing like blowing air gently, writing like rekindling.

How many times have I decided that I will not write any more? How many times have I written these doubts and hesitations, such as now? [48]

In the beginning of the essay I suggested a different view of narrative-and of lingual communication in general - than the conventional one. Narratives of lives and of lived experiences-such as backpackers' Romantic stories and young scholars' modern dissertations - entail enactment and not only present a discernable "reality" (GERGEN 1994; SHOTTER 1993; WORTHAM 2001). I have tried to show here, using an autoethnography, how personal narrative enacts, performs and evokes, rather than conveys. I suggest that in addition to "unity" and "direction" we should regard as central experience and relationships in forming meaning in narrative. [49]

\section{Epilogue}

My aunt asked me Where did I travel to for such a long time. I told her To Japan. My aunt asked me That Japan you traveled to what is it and how is it and what did you find there. And I didn't know the answers.

YA'AKOV RAZ, Tokyo and Back (2000)

The above dialogue is taken from the epilogue of a poetic journal of a journey. In one section, RAZ describes the way an old Japanese stone-gardener talks about the rocks and stones he "grows" and nurtures in his garden, with more affection and warmth than most people talk about their siblings. The journey, on which RAZ embarked, across the southern parts of Japan, followed the footsteps of another journey and another journeyer-the famous Haiku writer BASHOprecisely three centuries earlier (1689-90). [50]

Following RAZ's awe and bewilderment at his extended journey, I, too, am puzzled: What was it I wrote in the dissertation? What was it I wrote about? Swarthmore (where my post-doc is presently taking place), Jerusalem, the hissing screen, and my mothers' departure-are now one. [51]

9 Following poet YEHUDA AMICHAI'S verse in "Your Life and Death, Father" (1956): "I who was your hope/Now am hoped no more." (In HARSHAV and HARSHAV 1994, p.16.) 
To publish or perish? If you think of it enough, if you quote it from one context to another, the saying sounds eerie. Some people published and perished. Others perished because they published. [52]

I am here because I know I have to publish, i.e., write. (I don't want to perish.) I am not sure what it is exactly that I am writing about, nor whether this is even the central question at stake, nor whether I understand the relationship between ethnography, research, narrative, myself (researcher) and writing. I just know that here, in this occupation, I have to write. Not a privilege but a necessity. Deadlines for life-lines. [53]

A write of passage. [54]

\section{Acknowledgments}

I deeply thank Kenneth GERGEN and Matt KUTOLOWSKI for their comments on earlier versions of this paper. I would like to thank the Rothschild Foundation (Yad-Hanadiv) for a wonderful postdoctoral research year at the University of Pennsylvania and Swarthmore College, during which this paper was written. Parts of this paper were presented at the QUIG Conference on Interdisciplinary Qualitative Studies, The University of Georgia, Athens, January 4th 2002; and at the 2nd Annual Interdisciplinary Qualitative Approaches to Research Colloquium, Texas A\&M University, College Station, February 28th 2002.

\section{References}

Avrahami, Elyahu (2001). The Israeli Back-packers: A Study in the Context of Tourism and PostModern Conditions. Unpublished doctoral dissertation, CUNY, New York.

Becker, Howard S. (1986). Writing for Social Scientists. Chicago: The University of Chicago Press.

Bloch-Tzemach, Dalit (1998). Tourist, Dwelling Tourist and all the Rest. Unpublished master's thesis, The Hebrew University of Jerusalem, Jerusalem. (Hebrew).

Bochner, Arthur P. \& Ellis, Carolyn (Eds.) (2002). Ethnographically Speaking: Autoethnography, Literature, and Aesthetics. Walnut Creek, CA: AltaMira Press.

Dent, Beverly (2002). Border crossings: A story of sexual identity transformation. In Arthur P. Bochner \& Carolyn Ellis (Eds.), Ethnographically Speaking: Autoethnography, Literature, and Aesthetics (pp.191-200). Walnut Creek, CA: AltaMira Press.

Denzin, Norman K. (1997). Interpretive Ethnography: Ethnographic Practices for the 21st Century. Thousand Oaks, Cal.: Sage Publications.

Denzin, Norman K. (1999). Two-stepping in the 90's. Qualitative Inquiry, 5, 568-572.

Denzin, Norman K. \& Lincoln, Yvonna S. (1994). Preface. In Norman K. Denzin \& Yvonna S. Lincoln (Eds.), Handbook of Qualitative Research (pp.ix-xii). London: Sage Publications.

Derrida, Jacques (1988). Limited Inc. Evanston, IL: Northwestern University Press.

Derrida, Jacques (1990). Force of Law: The Mystical Foundations of Authority (M. Quaintance, Trans.). Cardozo Law Review, 11, 921-1045.

Eco, Umberto (1989). The Open Work (A. Cancogni, trans.). Mass.: Harvard University Press. (Original work published 1962)

Ellis, Carolyn (1993). "There are survivors": Telling a story of a sudden death. The Sociological Quarterly, 34, 711-730. 
Ellis, Carolyn (1997). Evocative autoethnography: Writing emotionally about our lives. In William G. Tierney \& Yvonna S. Lincoln (Eds.), Representation and the Text: Re-Framing the Narrative Voice (pp.115-142). Albany: SUNY Press.

Ellis, Carolyn (1999). Heartful autoethnography. Qualitative Health Research, 9, 669-83.

Ellis, Carolyn \& Bochner, Arthur P. (Eds.) (1996). Composing Ethnography: Alternative Ways of Qualitative Writing. Walnut Creek, CA: AltaMira Press.

Elsrud, Torun (2001). Risk creation in traveling: Backpacker adventure narration. Annals of Tourism Research, 28, 597-617.

Flemos, Douglas \& Green, Shelley (2002). Stories that conform/stories that transform: A conversation in four parts. In Arthur P. Bochner \& Carolyn Ellis (Eds.), Ethnographically Speaking: Autoethnography, Literature, and Aesthetics (pp.87-94, 115-122, 165-169, 187-190). Walnut Creek, CA.: AltaMira Press.

Frank, Arthur W. (1991). At the Will of the Body: Reflections on Illness. Boston: Houghton Mifflin.

Frank, Arthur W. (1995). The Wounded Storyteller: Body, Illness, and Ethics. Chicago: University of Chicago Press.

Garrett, Dean (2002). My Qualitative Dissertation Journey: Researching the Rules. New Jersey: Hampton Press.

Gergen, Kenneth J. (1994). Realities and Relationships: Soundings in Social Construction. Cambridge, MA: Harvard University Press.

Gergen, Kenneth J. (1999). An Invitation to Social Construction. London: Sage Publication.

Green, Martin B. (1993). The Adventurous Male: Chapters in the History of the White Male Mind. University Park, PA: Pennsylvania State University Press.

Gurevitch, Zali (2000). The Serious Play of Writing. Qualitative Inquiry, 6, 3-8.

Handelman, Don (1993). The absence of others, the presence of texts. In Smadar Lavie, Kirin Narayan, \& Renato Rosaldo, (Eds.), Creativity/Anthropology (pp.133-152). Ithaca: Cornell University Press.

Handelman, Don (1994). Critiques of Anthropology, Literary Turns, Slippery Bends. Poetics Today, 15, 341-381.

Harshav, Barbara \& Harshav, Benjamin (Eds.) (1994). Yehuda Amichai: A Life of Poetry (1948-1994). New York: HarperCollins Publishers.

Irigaray, Luce (1997). This Sex Which Is Not One. In Katie Conboy, Nadia Medina, \& Sarah Stanbury (Eds.), Writing on the Body: Female Embodiment and Feminist Theory (pp.248-256). New York: Columbia University Press.

Jackson, Heather J. (2001). Marginalia: Readers Writing in Books. New Haven: Yale University Press.

Jones, Stacy H. (1998). Kaleidoscope Notes: Writing women's Music and Organizational Culture. Walnut Creek: AltaMira Press.

Jones, Stacy H. (2002). The Way We Were, are, and Might Be: Torch singing as Autoethnography. In Art P. Bochner \& Carolyn Ellis (Eds.), Ethnographically Speaking: Autoethnography, Literature, and Aesthetics (pp. 44-56). Walnut Creek: AltaMira Press.

Josselson, Ruthellen \& Lieblich, Amia (2002). A Framework for Narrative Research Proposals in Psychology. In Ruthellen Josselson, Amia Lieblich, \& Dan P. McAdams (Eds.), Up Close and Personal: The Teaching and Learning of Narrative Research (pp.259-274). Washington, DC: American Psychological Association Press.

Labov, Bill W. (1972). Language in the Inner City: Study in the Black English Vernacular. Philadelphia, PA: University of Pennsylvania Press.

Lau, Kimberly, J. (2002). What a World of Technology Makes Possible: Toward a Performance Ethnography. Available at: http://www.sas.upenn.edu/folklore/ethnologist.html [August, 2002; changed permission, FQS, September 2003].

Maoz, Daria (1999). Libi bamizrach (My Heart is in the East): The Journey of Israeli Young Adults to India. Unpublished master's thesis, The Hebrew University of Jerusalem, Jerusalem. (Hebrew).

McAdams, Dan P. (1993). The Stories We Live: Personal Myths and the Making of the Self. N.Y.: William Morrow. 
McAdams, Dan P. (1997). The Stories We Live By: Personal Myths and the Making of the Self. N.Y.: Guilford Press.

McAdams, Dan P. \& Bowman Phillip J. (2001). Narrating life's turning points: Redemption and contamination. In Dan McAdams, Ruthellen Josselson, \& Amia Lieblich (Eds.), Turns in the Road: Narrative Studies of Lives in Transition (pp.3-34). Washington, DC: American Psychological Association Press.

Meloy, Judith M. (2002). Writing the Qualitative Dissertation: Understanding by Doing (2nd edition). MahWah, N.J.: Lawrence Earlbaum Associates Publishers.

Mevorach, Oded (1997). The Long Trip after the Military Service: Characteristics of the Travelers, the Effects of the Trip and its Meaning. Unpublished doctoral dissertation, The Hebrew University of Jerusalem, Jerusalem. (Hebrew).

Minh-ha, Trinh T. (1989). Women, Native, Other: Writing Postcolonialy and Feminism. Bloomington: Indiana University Press.

Noy, Chaim (2002a). "You MUST go Trek there-The persuasive genre of narration among Israeli tarmila'im (backpackers)." Narrative Inquiry, 12, 261-290.

Noy, Chaim (2002b). The Great Journey: Narrative Analysis of Israeli Trekking Stories. Unpublished doctoral dissertation, The Hebrew University of Jerusalem, Jerusalem. (Hebrew).

Noy, Chaim (2003). Narratives of hegemonic masculinity: Representations of body and space in Israeli backpackers' trekking narratives. Israeli Sociology, 5, 111-142. (Hebrew).

Noy, Chaim (forthcoming). This trip really changed me: Israeli backpackers' narratives of selfchange. Annals of Tourism Research.

Pirsig, Robert, M. (1974). Zen and the Art of Motorcycle Maintenance: An Inquiry into Values. New York: William Morrow and Company, Inc.

Raz, Yakov (2000). Tokyo and Back. Tel-Aviv: Modan Publishing House. (Hebrew).

Richardson, Laurel (1997). Fields of Play: Constructing an Academic Life. NJ: Rutgers University Press.

Ronai, Carol R. (1999). Sketching with Derrida: An ethnography of a researcher/erotic dancer. Qualitative Inquiry, 4, 405-431.

Salmon, Ruthi (1998). "A distant place, a worryless place": Motivations for participation in the backpacking trip, and gender influence. Unpublished Masters' thesis. Ramat-Gan, Bar-Ilan University.

Shotter, John (1993). Becoming someone: Identity and belonging. In Nikolas Coupland \& Jon F. Nussbaum (Eds.), Discourse and Lifespan Identity (pp.5-27). London: Sage Publication.

Shuman, Amy (1986). Storytelling Rights: The Uses of Oral and Written Texts by Urban Adolescents. Cambridge, MA: Cambridge University Press.

Simchai, Dalit (1998). "Untrodden, Not Always Marked, This Trail Starts Here...": Israeli Backpackers in the Far East. Unpublished master's thesis, Haifa, Haifa University. (Hebrew).

Sparks, Andrew C. (2002). Autoethnography: Self indulgence or something more? In Arthur P. Bochner \& Carolyn Ellis (Eds.), Ethnographically Speaking: Autoethnography, Literature, and Aesthetics (pp.209-232). Walnut Creek, CA: AltaMira Press.

Stewart, Susan (1991). Crimes of Writing: Problems in the Containment of Representation. Oxford: Oxford University Press.

Stewart, Susan (1993). On Longing: Narratives of the Miniature, the Gigantic, the Souvenir, the Collection. Durham: Duke University Press.

Tedlock, Dennis (1983). The Spoken Word and the Work of Interpretation. Philadelphia, PA: University of Pennsylvania Press.

Topol, Ellen R. (2001, June). Aesthetics and ethics of narrative inquiry: Exploring women's doctoral experience. Paper presented in the 13th Annual Conferences on Ethnography and Qualitative Research in Education, Albany, SUNY.

Tyler, Stephen A. (1986). A Post-Modern Ethnography: From Document of the Occult to Occult Document. In James Clifford \& George, E. Marcus (Eds.), Writing Culture: The Poetics and Politics of Ethnography (pp.98-122). Berkeley: University of California Press.

Wortham, Stanton (2001). Narratives in Action. New York: Teachers College Press. 
"The thesis is done. But the writing, the story, may be far from over."

An imagined conversation, in Stacy Jones, Kaleidoscope Notes

\section{Author}

Chaim NOY

I graduated from the Department of Psychology at the Hebrew University of Jerusalem, Israel (2002), and was on a Rothschild Postdoctoral Fellowship in the United States (the Department of Psychology, Swarthmore College, and at the

Center for Folklore and Ethnography, University of Pennsylvania). I am currently a M. Ginsberg Postdoctoral Fellow, at the Department of Sociology and Anthropology, Hebrew University, Jerusalem. My interests include qualitative and narrative modes of inquiry, combined with research of everyday experience, identity, tourism, and theories of social embodiment, particularly in the context of Israeli society.

\section{Citation}

Noy, Chaim (2003). The Write of Passage: Reflections on Writing a Dissertation in Narrative Methodology [54 paragraphs]. Forum Qualitative Sozialforschung / Forum: Qualitative Social Research, 4(2), Art. 39, http://nbn-resolving.de/urn:nbn:de:0114-fqs0302399.
Contact:

Chaim Noy

1/a Shalom Yehuda St. Jerusalem, 93395

Israel

Phone: 972-2-6732188

E-mail: chaimnoy@yahoo.com 